\title{
一解 説=
}

\section{氷 河 調 查 小史}

\author{
氷河学㤠談会編
}

\section{1. まえがき}

グリーンランドに拈ける故中谷字吉郎博士の雪水学的 研究, また, 日本の南極観測計画の一環に大陸氷の雪水 学的調査が正式に取り入れられるようになって以来, 近 年, 日本の研究者達も世界各地に現存する氷河に眼を向 け始め, 数多くの学術調査隊が氷河地域に派遣されるよ うになってきた。北は北極, アラスカから南はパタゴニ ア, 南極までと広範な地域に及び, 数多くの氷河学的業 績が残されている。しかし，それらの調查研究は研究者の 個人的興味からの問題のみに終ってしまい, 相互の連繫 がはなはだ弱かったということは否定できない事実であ る。今後これら個々の研究を有機的に結び，更に有効な 米河研究を発展させよ5とい5目的のために，本年 4 月, 北海道大学の中に氷河学愁談会が発足した。

この氷河調査小史は本郎談会発足の主旨に添い, 将来 の水河調査研究の一指針となり得る資料にするために, まとめられたものである。本小史を編集するにあたり， ぞこまでを本小史に含めるべさかが大さな問題である。 極地や高山での気象観測, また雲物理, 降水機構などの 研究, あるいはカールやU字谷等の氷触地形, また構造 上, ピンゴ等の周氷河地形等々の研究は, もとより氷河 学的研究と深い関係があることはいささかも否定するも のではない。しかし，これらの研究すべてを含めると相 当膨大な量になり，本硪談会の手の及ぶ範囲を越えてし ま5。したがって本小史に含まれるものは，日本人によ る現存水河の雪水学的調査研究のみに限ることにした。

\section{2. 展 望}

$$
\text { (1) }
$$

$$
\text { グリーンランド }
$$

$$
\text { 黑 岩大 助 }
$$

アメリカイリノイ州のウイルメットにあった雪氷永久 凍土研究所 (SIPRE といっていたが, 現在は寒地理工 学研究所, CRREL, と改称して ニューハンプシャー州 八ノバーに移転した）は1953年以来, グリーンランドの 水冠の雪氷学的研究所や永久凍土の研究調査を始めた。 北緯 $78^{\circ}$, Thule から約 230 マイル氷冠のなかに入った 標高 $2,100 \mathrm{~m}$ の地点にキャンプを設け, 氷冠の雪と氷の
層（厚さは $2,000 ３, 000 \mathrm{~m}$ ）を岩盤までボーリングでう ち抜こ という規模壮大な仕事である。故中谷宇吉郎は 1957年以来, このプロジェクトに参加し, コアーサンプ ルの物理的研究を始めた。グリーンランドの氷冠の上で は, 積雪はほとんど融解を経験することなしに圧密氷化 が進んでいる。ボーリングで掘り出されたサンプルを調 べると, この氷化過程を知る手がかりが得られるわけで める。中谷は, 北大低温科学研究所が開発した粘弾性湘定 装置と, 積雪の内部樍造を少しの变化も与えることなし に調べることができる顕微鏡用薄片製作技術とを駆使し て，グリーンランドの自然積雪や人工的に処理した雪の 粘弾性的性質をその内部構造と関連させて調べた。積雪 を氷の粒と空気との混合物とみなすと, 積雪は密度が小 さいらちは空気のなかに氷の粒が分散した形をとってい る。ところが, 密度が大きくなって氷に近づくと分散媒 と分散相の立場は逆になって，氷のなかに空気が分散す ることになる。積雪粒子自身が変形することなしに压密 されうる限界は，せいぜい密度にして0.5E位までと考え られている。これ以上王密されるためには, 氷の粒自身 が塑性変形しなければならない。やがて空吵が小さな気 泡となって氷のなかに閉じこめられはじめると，むはや 密度を增すためには気泡自身が収縮する以外に方法はな い。この積雪が通気性を失了限界の密度は 0.83 ぐらいと いわれている。中谷はこのよ5な圧密にともな5雪氷の 物理的性質の変化をその内部構造と関係づけて詳しく解 明しようと計画したが，志半ばにして病魔にたおれた。

1962年 4 月 21 日〜 5 月 6 日の間, 黒岩はグリーンラン ドの TUTO 付近にある氷河にあけられたトンネルと, 永久凍土層内につくられたトンネルとを調査した。氷河 トンネルの規模や内部の施設については，「天文と気象」 29巻 3 号1963年に書いたのでここでは永久凍土トンネル についてのべる。このトンネルは, キャンプ TUTOか ら Thule に向う道路から数 $\mathrm{km}$ 入った, モレーンの傾 斜地につくられていた。奥行は 50〜 $60 \mathrm{~m}$ あり, 中央に は電動機で動くトロッコが走るレールが教いてあった。 トンネル内部の温度はどこも一定で約 $-10^{\circ} \mathrm{C}$ であっ た。周りの壁はかたく凍結した灰色のシルト層であっ 
て,どうしてこんなに厚いシルトの層が, 岩石のごろこ ろしているモレーンの下に横たわっているか不思議であ る。トンネル内部の天井から周りの壁は床上 $1 \mathrm{~m}$ 位を 除さささをさまな形の巨大な霜の結晶で被われていた。 結晶は大きいもので直径が $4 \sim 5 \mathrm{~cm}$ も めり, 六角形 のヘリカル，四角なコツプ，細長い鞘状のものなどいろ いろ珍しいものがあって, 静寂な暗闇のなかに結晶底面 がキラキラと鏡のように輝いていた。霜の結晶はトンネ ル入口から奥に進むに従って厚みがうすくなっていたか ら，入口から侵入してくる外気の水蒸気がトンネルの壁 に犁華したものと思われる。トンネルの一番奥は大広間 になっていて，いくつかの部屋に分割されており，広間 を支える柱も壁も，ベンチやテーブルまですべて凍土を くり抜いて整形したものであった。凍土のベンチにしば らく腰をかけていて立上ると,とけた泥がべっとりとく っついて衣服を污した。

最近の情報によると，CRREL は TUTO キャンプ を閉鎖したそうであるから，莫大な金をかけてっくった 氷河トンネルるやがては氷の流動によっておしつぶされ てしまうであろう。

\section{(2) アラスカ}

東晃

アラスカは, 日本の研究者による氷河調查の本格的な ものの初舞台でめったと言える。1960年に第 1 次アラス カ水河調查隊 (北海道大学) がメンデンホール氷河にお もむく以前には, 南極観測の一部に地理学的調查として の氷河調査があったに過ぎない。

氷河調査といえば,ややり単なる氷河の存在形態の問 題ではなく, 水河の消長, 質量収支, 熱収支, 流動, 氷 河水の形態変化といったダイナミカルな問題を取扱うの が第一義と考兄られる。上記第 1 次隊の半分の目的は, メンデンホール氷河に産出する氷の巨大単結晶を物性研 究の材料として多量に採取して北大に持ち帰ることであ ったが, それと同時に, この巨大単結晶形成の機構を確 かめるための氷河学的調査を行ならことが残りの半分で めった。そういう調査がどんなものであるべきか，また， 氷河氷のマクロな形態もミクロな構造もよく知られてい なかったので,この調査の報告を「自然」に執筆したと きは, 単なる報告にとどまらず, 氷河調査法や氷の形態 に関する解説をかねたものとした。調查の詳細は，その 報告に譲ることとする。なお，この水単結晶の成長の問 題は1964年の第 2 次隊に引継がれ，氷河上に打いたスト レイン・グリッドによる歪測定の結果, 歪緩和の機構に よって説明されたことをつけ加えておく。
第 2 次隊は, アントラー氷河においてオーギヴ生成の 問題をとり上げ, また, カスカウルシュ氷河においては源 流の積雪の断面観測を行なっている。前者においては, オ 一ギヴの生成が従来言われているょうに，氷崖の流速の 季節的变動による氷面の形状によるだけでなく, 氷の形 態変化による砂砂捕捉の差が関与しているらしいことを 提案した。後者においては,この高緯度 $\left(60^{\circ} 45^{\prime} \mathrm{N}\right)$ の $2,600 \mathrm{~m}$ の源流域においても, 積雪内温度分布が温暖水 河の特徴を示すという結果を得た。

アラスカの海岸山脈から流出する数多くの氷河の中に は,このように単一の研究テーマに適合した, 大きさも 手頃な氷河が沢山ある。その中から接近の割合容易なる のを選んで少し長期的な調査観測を行ならことは, 氷河 学の中のある特定の問題に対しては大变有効であろろと 思われる。カスカウルシュ氷河を中心にして行なわれて いる北米北極研究所の IRRP (Icefield Range Research Project）なども,このような意図の下にいくつかの問題 に対して共同の作戦がとられているものであろう。フラ スカ大学やオ八イオ大学, ミシガン大学等の計画もかな り長期にわたって継続されている。今後, 我々がアラス カを調査の対象としてみるときは，そうい5問題の選定 と継続的な仕事の体制が必要になるであるう。

1968年冬に行なわれた北極水圈調查隊（名大と北大の 合同）は,こういう問題探しの一つであったとみられ る。冬季間の氷河の状態を知り, 降雪, 積雪の観測を行 なって北極水圏の水のサイクルを押兄るためには，観測 の体制と研究者の増加が益々必要になるであろう。

なお，氷河調査の範囲を外れるが，北極圈の雪水学的 調查としては, 上記の北極水圈調查隊が、ここに記載さ れたメンデンホール氷河の調查の他に, アラスカのバロ 一, フェアバンクス, アンカレッジ等の各地で降雪と積 雪の観測を行なっており，また，北大の六車と菊地か 1962年に北極海岸のピータース湖の湖水の研究を行なっ たものがある。

\section{(3) ヒマラヤ}

渡 辺興 亜

ヒマラヤ山脈は亜熱帯に位置するが, 山脈の平均高度 が高いことと、気候条件が氷河形成にとって有利である ため, 氷河が上く発達している。しかし, この地域の水 河調査は, 接近の困難の故をもってか, きわめて少な い。ヨーロッパ・アメリカの調查隊による氷河調査も Miller, Untersteiner ら 2,3をのぞいてほとんど見当ら ず,むしろ量的には日本人によるものの方が多いようで ある。氷河調査は今後に残されたヒマラヤ地域の自然調 
査の重要なるのの一つであるが, 気象・気候・地形など の基礎的資料が皆無に近い状態なので, 氷河の一般形 態・分布など氷河学に打ける基礎的情報の概略が明らか にされるまでには多くの困難が予想される。これまでに 日本隊によって行なわれた氷河学に関係する仕事は, 主 として気象観測である。しかし，一定地域で長期間連続 観測を行ならことが困難なため，いずれる断片的資料の 域を脱していないと思われ，ヒマラヤ地域に打兴氷河 形成に関与する気象条件の解明には，まだ不十分といわ さるを得ない。構造氷河学的研究や流動に関する研究に おいても先にのべたような水河の形態・分布に関する基 礎資料がきわめて少ないため、それらに適した氷河の選 定段階においてすでに困難が生じるような状態である。 しかし，ヒマラヤ地域（カラコラムも含めて）を登山, 調査の目的で訪れた日本隊は怙そらく数十に及ぶと思わ れ，その潜在的資料は膨大なるのと予想される。日本・ ネパール文化協会などの努力によって，その一部はネパ ール・ヒマラヤ探検記録（日高信六郎編）としてまとめ られているが, 承河学の分野においても同様な仕事が期 待される。国際水文学十年計画の一環として，中島啺太 郎（京大), 桶口敬二 (名大) らのグループが, その仕 事に着手している。

ヒマラヤ地域は現存氷河の研究にとってきわめて興味 深い地域であるが、同時に，気候変動にもとづく氷河の 変動およびそれらを一つのカギとする第四紀学の分野な どにとっても興味深い地域であり，日本と同じアジア地 域にある自然として，日本の自然および自然史と重要な つながりをもっていると考兄られる。いずれの場合にお いても, 組織的な研究が要望される。

\section{（4）パタゴニア}

\section{成 瀬 廉二}

パタゴニアの氷河に打ける調査は，現在までのところ 数少い。代表的なものは L. Lliboutry 等の数度にわた る調查がめるが (参照 Nievesy Glaciares de Chile), 氷河調査としては第一段階的なるのに終っている。その 他, 地質調査の際に水河を観察したもの, 航空写真によ る氷河の前進・後退の観察, および氷触地形等の研究 は,アメリカ, チリ, アルゼンチンなどによっていくつ か行なわれている。

日本人に批ける氷河調査は, 安間らの第一次調査隊の 観察が最初である。安間らは地質調査が主体だったが， ティェラ・デル・フェゴのサルミェント峰の登頂の際, また, 南部パタゴニアのパイネ山付近のグレイ氷河など において氷河上を長期間行動し, 多くの観察を行なって
いる。翌年の第二次調查隊は，パタゴニア北部のサンパ レンティン山周辺に流れ出ているいくつかの氷河におい て, 末端部から中流付近にかけて種々の観察を行なっ た。第一次, 第二次隊ともに雪水学的水河調查としては初 歩的なるので，予借調査の域を出ていない。しかし，パ タゴニアの温暖水河を日本に紹介したという功績は認め てよい。今後, 更に本格的な調査, とくに気候と関連さ せた研究が行なわれることが強く望まれる。

\section{(5) 南 極}

$$
\text { 石田完 }
$$

1912年 1 月19日，日本隊がロス亦棚に第一歩をふみだ し, $80^{\circ} 05^{\prime} \mathrm{S}, 156^{\circ} 37^{\prime} \mathrm{W}$ に達した隊長白瀬橴。学術部 長武田輝太郎らの犬ぞり隊のことを忘れることはできな いが, もちろん, 日本が本格的な南極地域の学術調查を 開始したのは1957年である。以来，1C年間にのべ 126 名 が越冬しているが，その5ち雪水学研究者は1960年の第 4 次観測隊以来 3 名にすぎない。日本の南極観測におけ る雪氷学的研究は，いまだまことに微々たるものといわ さるる得ない。

しかし，専門外ではあるが，地学関係の観測者によっ て年々, 沿岸の水河, 内陸の雪水調査が行なわれ, 航空 機を持たない日本隊としては，かなり広範囲に調査が広 がってきた。第 1 次隊は犬ぞりにより，北は日の出岬か ら南はボッンヌーテン山に至る約 $350 \mathrm{~km}$ の調査がなさ れ, 第 3 次隊では内陸 $350 \mathrm{~km}\left(70^{\circ} 24^{\prime} \mathrm{S}, 46^{\circ} 50^{\prime} \mathrm{E}\right)$ ま で雪上車による調査, 第 4 次隊ではやまと山脈まで, 第 5 次隊はやまと山脈を経由して更に $75^{\circ} \mathrm{S}$ まで, 第 8 次 隊は $43^{\circ} \mathrm{E}$ 線沿いに $79^{\circ} 15^{\prime} \mathrm{S}$ の Plateau Station まで, 初めて大型雪上車 3 台による大型調查がなされ, 現在第 9 次隊は, このルートを更に延長して極点までの調査を 行なおうとしている。このように, 調査範囲が次第に拡 大しているが, 調查は点あるいは線上のみに留まり, 観測 方針, 方法も統一したものに乏しかった。したがって, 調 查報告も単発的なものに留まっている。ただ, ラングホ ブデ水河では第 6 次隊以来, 年次毎に観測が行なわれ, とくに流速の測定に努力がはらわれているが，毎回次年 度に標旗が流出して, 観測に失敗している。これは当水 河が昭和基地に最も近いわりに，ヘリコプター無しでは 近づきがたい場所にあり，標旗の立て方に十分な工夫が なされなかったことにもよるが残念なことである。

これまでの調査は, 昭和基地周辺の氷河および大陸水 をなるべく広範囲に観察するという目的で一応成果を得 たと思われる。今後は，一貫した観測方針に基づき, 更 に詳細な研究に移行する段階にあると思われるが、現 
に，第10次，第11次隊ではやまと山脈東方地域の大陸水 の収支, 移動の観測に重点を置いた, いわゆるエンダー ビーランド地域雪水学的長期調査計画がなされており, 期待される所である。現在まとまった報告は出版されて いないが，これまでの経過の概要を知る上には南極六年 史 (文部省, 昭和38年発行) が参考になる。なお，本小 史に含まれたもの以外飞, 第 3 次隊, 第 4 次隊におい て, 昭和基地周辺の海水・氷山の調查が，小野，鈴木等 によってなされている。

\section{3. 小史}

日本人によって過去に行なわれた氷河調査を, 地域別 に北から南へ, また, 同一地域内では年代順にならべて ある。1968年 6 月30日現在。

\section{(凡例)}

\section{1. 調查隊名;}
a) 隊長名 (所属**)
b) 調查担当者名 (所
属） c) 調查地 d) 調查期間 e) 調査概要
f）報告書, 出版物 $\mathrm{g}$ ) 資料***

（注）

*調査隊では正式名のないものは一一とする。 日本南極地域観測隊は JARE と略す。

JARE. 1 は第 1 次観測隊の意。

**隊長ならびに調査担当者の所属は原則として現在 のものとする。所属は次のように略す。 北……北海道大学, 東……東京大学, 名……名古 屋大学, 京……京都大学, 広……広島大学, 理… …理学部, 工……学部, 文……文学部, 農…… 農学部, 獣……獣医学部, 教……教養学部, 低… …低温科学研究所, 水……水質科学研究施設, 科 博……国立科学博物館, 極振……極地 研 究 振 興 会, 気……気象庁, 地……国土地理院,

*** 地図, 案内書など。

(1)

a) 中谷宇吉郎 (元, 北 - 理, 故人)

b) 六車二郎 (北・工), 桶口敬二 (名・水), 中谷宇 吉郎 (故人), 楠 宏 (科博)

c) 水島 T-3 d) $1959.5 \sim 1960.9$.

e) 氷の morphology, ablation, petrofabrics, viscoelastic property, cloride contentなどの調查。試 料の一部を北大において結晶構造, 氷中の dust のX線解析など。

f)

1) Glaciological Studies on Fletcher's Ice Island (T-3); U. Nakaya, J. Muguruma, K. Higu- chi, Arctic Inst. of North America, Research Paper No. 21, 1962.

2) Physical Properties of the Ice of Fletcher's Ice Island (T-3); U. Nakaya, J. Muguruma, Ditto. Research Paper 20, 1962.

3) Glaciological Studies on Ice Island (T-3); J. Muguruma, K. Higuchi, J. Glaciology, 1963, Vol. 4, No. 36.

g）資料は主に六車保管。

(2)

a) b) 中谷宇吉郎 (元, 北 - 理, 故人)

c）グリーンランド水冠。

d) 1957 1960の夏期。

e）グリーンランド氷冠の自然の雪と氷，および人工 的に処理した雪の物理的性質をその内部構造之関 連づけて研究。

f)

1) Visco-elastic Properties of Snow and Ice in the Greenland Ice Cap; U. Nakaya, SIPRE Research Report 46, (GRREL, Hanover, N. H., USA) 1959.

2) Visco-elastic Properties of Processed Snow; U. Nakaya, SIPRE Research Report 58, 1959.

3) Elastic Properties of Processed Snow with Reference to Its Internal Structure; U. Nakaya, SIPRE Research Report 82, 1961.

4) Physical Properties and Internal Structure of Greenland Snow; U. Nakaya and D. Kuroiwa, Proceedings of International Conference on Low Temperature Science, 1966.

より詳細な研究報告は CRREL より出版され る予定。

5）グリーンランド承冠の粘弾性, 中谷宇吉郎, 科 学, 28巻, No. 1, 1958.

(3)

a) b) 黒岩大助（北・低）

c) グリーンランド TUTO の水河及び永久凍土トン ネル

d) 1962. 4. $21 \sim 1962.5 .6$.

e)グリーンランド TUTO の氷河トンネルおよび永 久凍土トンネルの調查ならびに氷河湖 の水の調 查。

f）黒岩大助, 米のなかでの生活; 天文と気象, 29巻, 3 号, 1963。

g) 水河トンネル内部, 水湖, グリーンランドチュー 
レ付近のカラースライドあり。

（4）第1 次アラスカ水河調查隊

a) 東 晃 (北・工), b) 東 晃 (北・工), 橋本 誠二 (北・理), 板坂和彦 (北・理), 清水 弘 (北・低), 熊野純男 (北・理), 菊地勝弘 (北・ 理), 高橋 劭 (名・水)

c）メンデンホール氷河 (東南アラスカ)

d) $1960.5 .23 \sim 7.20$.

e) メンデンホール氷河における巨大単結晶水の生成 過程を調べる目的で, 氷河の下流域, 中流域に拉 ける流速分布の測定, 水の $\mathrm{C}$ 軸方向分布の測定, 種々の表面構造の観察, 上流域の探査等。末端の 氷河湖に浮んでいる氷山から巨大単結晶の採集打 よび持ち帰り。

f)

1）メンデンホール氷河の調查 (I ) ; 東 晃, 橋 本誠二, 自然, 16巻, 2 号, 1961年。

2) メンデンホール氷河の調査（II）；東 晃, 橋 本誠二, 自然, 16巻, 3 号, 1961年。

3）水河に怙壮る氷の結晶生長; 東 晃, 金属物 理, 7 巻, 1 号, 1961年。

4) アラスカ水河調查隊の食糧について；菊地勝 弘, 雪水, 26 巻, 2 号, 1964年。

g）地図 U.S.G.S. の $1 / 63,360$ 及び $1 / 250,000$ 多 数, 近接の Juneau Icefield における Maynard Miller 博士らの仕事仪関する報告等の文献多数, いずれも北大工学部庥用物理学教室, 東 晃のも とに保管。

（5）第 2 次アラスカ水河調查隊

a) 東晃 (北・工) b) 東 晃 (北・工), 橋本 誠二 (北・理), 清水 弘 (北・低), 若浜五郎 (北・低), 中村耕二 (北・理), 田沢誠一 (元, 北・理, 故人)

c) メンデンホール水河, アントラー氷河（東南アラ スカ), カスカウルシュ氷河（カナダ）

d) 1964.6 . 13 7. 27 .

e) メンデンホール氷河においては前回に引き続き巨 大単結晶成長の機構を明らかにするため, 氷河下 流域に批いて歪速度測定。アントラー氷河におい ては，その顕著なオーギヴの観察と測定。カスカ ウルシュ氷河では, 源流域の 積雪のボーリング $(15 \mathrm{~m})$ による断面観測。フェアバンクス地域の永 久涷土層, グルカナ水河のフォリエーション, カ トマイ火山等の見学。

f)
1）カスカウルシュ氷河（カナダ）源流域における 積雪調查; 清水 弘, 若浜五郎, 低温科学, 物 理篇，第 22 輯，昭和 40 年。

2) 極地水河之温暖水河；東 晃, 地理（古今書 院)，第 11 巻，第 3 号，昭和 41 年。

3) Glaciological Studies of the Antler Glacier, Alaska; S. Hashimoto, H. Shimizu and K. Nakamura, Journal of the Faculty of Science, Hokkaido Univ., Ser., IV, Geology and Mineralogy, Vol. XIII, No. 3, 237 256, 1966.

4) Ice Crystal Growth in a Temperate Glacier in Alaska; A. Higashi, Physics of Snow and Ice, Proceedings of the International Conference on Low Temperature Science, 1966, Vol. 1, Part 1, Dec. 1967.

5 ) 水河 (単行本) ; 東 晃, 中央公論社, 昭和 42 年。

g) 地図, U.S.G.S. の $1 / 63,360,1 / 250,000$ 及び Canada の D.M.T.S. の 1/250,000 等関係地域 のもの一通り。北大工学部応用物理学教室, 東 晃のもとに保管。

（6）北極水圈学術調查隊

a) 桶口敬二 (名・水)

b) 若浜五郎 (北・低)

高橋 劯 (名・水)

c) メンデンホール水河

(東南フラスカ)

d) 1968 . 3. 1 3. 13 .

e) メンデンホール水河の冬期間の流動測定, 水河水 の組織扣よび電気的性質の測定, $7 \mathrm{~m}$ のボーリン グ・コア資料の持ち帰り。

f) 未発表。

g）地図 U.S.G.S. $1 / 63,360$, 案内書, 若浜のもとに 保管。

（7）日本大学ムクト・ヒマール学術調査隊

a) 石坂昭二郎 b) 宮原 魏（日大山岳部O B ) 平山善吉 (日大山岳部O B )

c）ムクト・ヒマール及びその周辺。

d) $1962.4 .9 \sim 6.30$.

e) 気象調査, 氷河の一般的観察, 雪の結晶の観察。

f）日本大学ムクト・ヒマール学術調査隊報告書; 日 本大学ヒマラヤ委員会, 1962年。

（8）北海道大学西ネパール遠征隊

a) 安藤久男 (北海道開発局)

b) 渡辺興覀 (名・水) c) 西ネパール・カルナリ 河上流,タクプ氷河。

d) 1963. 10. $20 \sim 11.4$. 
e) タクプ氷河について

1) 構造記載 2) 水河および氷河周辺地形測量

3）流動量測定 4）氷の構造, 粒度測定 周辺部で

1）気象観測 2）氷蝕地形の記載

3）雪線高度の観測

f)

1）北海道大学西ネパール遠征隊報告; 遠征隊事務 局，木崎甲子郎 (発行人), 1964年 7 月 15 日。

g） $1 / 500,000$ 及び $1 / 250,000$ の地形図, 写真多数。

（9） 京都大学ネパール・ヒマラヤ遠征隊

a) 桶口明生（京・防災研） b）桶口明生（京・防 災研), 上田 豊 (名・水)

c) 中央ネパール・アンナプルナ山群, 南アンナプル ナ氷河, ガネッシュ氷河。

d) $1964.9 .17 \sim 10.30$.

e）気象観測，氷河上の積雪観測，雪崩の観測。

f)

1）ネパール・ヒマラヤ遠征隊報告, 京大山岳部報 告; 13号, 1966年。

2) ガネッシュの蒼い氷 (単行本) 朝日新聞社, 1966年。

（10）北海道大学中央ネパール地質水河調査隊

a) 酒匂純俊（北海道地下資源調査所）

b) 渡辺興亜 (名・水), 遠藤八十一（北・低）

c) 中央ネパール・ガンダキ地区, ダウラギリ山群, グスタング氷河。

d) $1965.10 .30 \sim 11.4$.

e) グスタング氷河にて

1) 氷河扣よび周辺部地形測量

2) 氷河構造の記載

周辺部にて

1）気像観測，2）氷蝕地形の記載，3）雪線高度 の観測。

f)

1）中央ネパール；酒匂純俊 (発行人), 1968年 6 月 15日。

2）ヒマラヤの氷河（I）；渡辺興亜, 遠藤八十一 石田隆男, 低温科学, 第25輯 物理篇。

(11)
a) 桶口明生（京・防災研） 災研)
c) 東ネパール・カンチェンジュンガ山群, ヤルン氷 河, 及びその周辺。
d) $1967.4 . \quad 20 \sim 6.30$.

e）承河上に护なる気象観測, および氷河周辺部の気 象観測

f）プレモンスーン期における東部ヒマラヤの氷河上 の気象観測について; 中島暢太郎, 樋口明生, 京 大防災研年報, 第11号, 1968年。

(12)

a) b) 山田知充 (北·低), 神谷晴夫 (北 獣)

c）ネパール（クンブー地方, カリガンダキ上流部ゴ ザインクンド)

d) $1967,11 \sim 1968,2$.

e）クンブ一地方でェベレスト付近の水河の一般的観 察。チャングリナップ氷河の雪水学的観察。ゴザ インクンド方面で積雪観測等。

f）未発表。

g) 気象観測 (目視) 資料。ネパール気象庁よりネパ 一ル全部の観測 station の観測資料。1965，1966 のネパール水文観測 station の観測資料。クンブ 一地方の $1 / 50,000$ 地形図。

（13）パタゴニア計画第一次調査隊

a) 辻井達一 (北・農)

b) 安間 荘 (基礎工学研究所), 遠藤禎一（サンコ ーコンサルタント), 西村 豪 (チリ大学)

c) サルミエント水河 (フェゴ島), グレイ氷河（パ タゴニア南部)。

d) $1966.1 .10 \sim 3.20$.

e) 南部パタゴニアの氷河の一般的観察。

f）末発表。

g）パタゴニアほぼ全域の $1 / 250,000$ の地図。（北大 植物園に保管）

（14）パタゴニア計画第三次調査隊

a) 吉田博直 (広・理)

b) 成瀬廉二 (北・低), 遠藤祯一（サンコーコンサ ルタント)

c) 北部パタゴニア, サンバレンティン山周辺の氷 河。特にソレール氷河。

d) $1967.2 .20 \sim 3.30$.

e) サン・ラファエル氷河, シルコ氷河, パンパ・デ. ニエベ氷河の主に末端付近の観察。ソレール氷河 に扰いて, Ablation, 表面流動量の簡単な観測。

f）パタゴニア北部の氷河調査；成瀬廉二，遠藤禎 一, 雪氷, 29 巻, 6 号, 1967年。

g）パタゴニアほぼ全域の $1 / 250,000$ の地図。（北大 植物園に保管）

(15) JARE. 1 

a) 西堀栄三郎（原子力船開発事業団）
b) 立見辰雄 (東・理), 菊地 徽 (三菱釯業)
c）ボッンヌーテン山地区，およびプリンスオラフ沿 岸。
d) 1957. 5 月, 8 月, 10 11月。
e）地形, 表面状況。
f)

1）南極昭和基地付近の地学的観察（その 1)；立 見辰雄, 菊地 徹, 南極資料, 7 号, 1959年。

2) 南極昭和基地付近の地学的観察 (その 2 ) ; 立 見辰雄, 菊地 徹, 南極資料, 8 号, 1959年。

（16） JARE. 1 a) 氷田 武(東・理)

JARE. 3 a) 永田 武 (東・理)

JARE. 6

a) 吉川虎雄 (東・理)

b) 国土地理院

c) プリンスオラフ,プリンスハラルド沿岸。

d) $1957, \quad 1 \sim 2$ 月 (JARE. 1) $1959 . \quad 1 \sim 2$ 月 (JARE. 3) 1962. $1 \sim 2$ 月 (JARE. 6)

e) 航空写真撮影。

f)

1）第 1 次隊，第 6 次隊の航空写真による解析結 果; 大浦浩文, 山田知充, 南極資料, 26 号, 1966年。

2）昭和基地周辺の水河, 地質に関する写真判読結 果；中野尊正，鉔治晃三，原田美道，南極資料 10号，1960年。

g) 地図及び写真集, 南極空中写真集, 国土地理院, 1968年 3 月発行。

(17) JARE. 3

a) 村山雅美（科博） b) 村内必曲（科博）

c) 内陸 $46^{\circ} 50^{\prime} \mathrm{E}, 70^{\circ} 24^{\prime} \mathrm{S}$ まで。

d) $1959.4 .1 \sim 4.20$ 及び 1959. 10. 10 11. 12 .

e) 氷厚地震探査, 地形, 気象。

f) 未発表。

(18) JARE. 4

a) 鳥居鉄也（極振）

b）石田 完(北・低), 木崎甲子郎(北・理), 吉田栄 夫 (広・文)

c) やまと山脈 d) 1960.11 .12 12. 15.

e) 水厚地震探査, 内陸表面地形, やまと山脈周辺水 河地形。

f)

1）第 4 次越冬隊やまと山脈調査旅行報告 (予報); 鳥居鉄也, 吉田栄夫, 木崎甲子郎, 石田 完,
南極資料，13号，1961年。

2) やまと山脈調查旅行の途次に扣ける人工地震探 査; 石田 完，南極資料，14号，1962年。

3）やまと山脈の地形; 吉田栄夫, 藤原健藏, 南極 資料，18号，1963年。

(19) JARE. 4

a) 鳥居鉄也（極振）

b）石田 完 (北・低), 木崎甲子郎 (北・理), 吉田 栄夫 (広・文)

c) ハムナ, ホノールブリニツガ。

d) 1960. 5. 17 1960. 5, 25 .

e) 地形, 氷河構造, 流速。

f）南極，ハムナ氷瀑およびホノールブリュツガ氷河 における構造水河学の研究; 木崎甲干郎, 南極 如料，16号，1962年。

(20) JARE. 4

a) 鳥居鉄也（極振）

b) 石田 完 (北 - 低), 木崎甲子郎 (北・理), 吉田 栄夫 (広・文)

c) 白瀬水河 d) $1960.4 .15 \sim 1960.5 .25$.

e）地形，気象長期自記，流速。

f) 雪水, 地理; 吉田栄夫, 石田 完, 南極観測第 4 次越冬隊報告 (南極特別委員会日本学術会 議), 1961年。

(21) JARE. 5

a) 村山雅美 (科博)

b) 大浦浩文 (北・低), 藤原健藏（広・教）

c) やまと山脈経由 $75^{\circ} \mathrm{S}$ まで。

d) $1961,10,4 \sim 1961,12,19$.

e) 水厚地震探査, 重力, 地磁気, 地形, 雪質。

f)

1）昭和基地より南緯 75 度までの旅行およびクック 岬への旅行に拈ける重力測定について；大浦浩 文，南極資料，25号，1965年。

2) 東南極みずほ高原の形態について；藤原健藏, 南極資料，23号，1964年。

(22) JARE. 5

a) 村山雅美（科博）

b）大浦浩文 (北 - 低), 清野善兵衛 (気), 藤原健藏 (広・教)

c) 内陸 $69^{\circ} 07^{\prime} \mathrm{S}, 40^{\circ} 14^{\prime} \mathrm{E}$ 地点。

d) $1961.3 .15 \sim 3.20,5.17 \sim 5.18$ 。 1962. 1 . 15 。

e) 気象長期自記観測, $10 \mathrm{~m}$ 下雪温年間連続観測。

f) 未発表。 
(23) JARE. 7

a）武藤 晃（川口市医師会病院）

b) 前小屋端 (京都産業大学)

c) $69^{\circ} 07^{\prime} \mathrm{S}, 40^{\circ} 14^{\prime} \mathrm{E}(\mathrm{L} / \mathrm{L})$

d) $1966.11 .2 \sim 1966.11 .3$.

e) 雪温, 積雪量。

f）雪水；前小屋端, 日本南極地域観測隊第 7 次越冬 報告（南極地域観測総合推進本部），1967年。

(24) JARE. 7

a) 武藤 晃（川口市医師会病院）

b) 印部英一 (地), 前小屋端 (京都産業大), 石田 完 (北・低), 吉田栄夫 (広・文)

c) ラングホブデ d) 1966. 10. 23 および 1967. 2. 5 。

e) 地形測量, 流速測定

f）雪氷；前小屋端, 日本南極地域観測隊第 7 次越冬 隊報告, 1967年。

(25) JARE. 8

a) 鳥居鉄也 (極振)

b）石田 完（北・低），吉田栄夫（広・文）

c) ラングホブデ d) $1967,10,12 \sim 1967,10,14$ 。

e）地形測量，流速測定標旗設置。

f）末発表。

(26) JARE. 8

a）鳥居鉄也（極振）

b) 石田 完 (北 - 低), 鳥居鉄也 (極振), 吉田栄夫 (広・文)

c) 東経 $43^{\circ}$ 線沿い上陸点から Plateau St. まで。

d) 1967. 11.5 1968. 1. 15.

e) 氷厚地震探査, 重力, 地磁気, 表面地形 (高度, サスッルギ, 雪質), ピット, ボアホールによる 雪水調査,ネーへの化学分析, 気象観測。

f) 未発表。

g）ネーペのコアサンプル若干（深さ $6 \mathrm{~m}$ ま゙），低 温研保管。

(27) JARE. 8

a）鳥居鉄也（極振）

b) 石田 完 (北・低), 遠藤八十一 (北・低), 江頭 庸夫 (京・防災研桜島火山観測所)

c) ラングホブデ $\quad$ d) $1968.1 .29 \sim 1968.2 .2$ 。

e) 氷河地形観察, コアーサンプリング, 流速測定用 標旗設置。

f）末発表。

（28）第13次オーストラリア南極探検隊

a) K. Morrison b) 木崎甲子郎（北・理）

c）モーソン基地西部の水床。

d) $1966.2 \sim 1967.2$.

e) 流速, アブレイション, ストレイングリッド 3 個 による歪量測定, 氷河図作製, ペトロファブリツ クス, その他, 自動スティションによる微気候学 的測定, 海水調査。

f) Petrofabric Study of Mawson Region, East Antarctica；Jour. Glaciology 投稿中。

g) Antarctic Division, Department of External Affairs, 568 St. Kilda Rd. Melbourne, 3004, Australia にあり。

（29）第13次オーストラリア南極探検隊

a) K. Morrison

b) 木崎甲子郎 (北・理) c) Forbes Glacier (モソン基地より約 $20 \mathrm{~km}$ 西)

d) 1966. 2 月の 2 週間, 1966. 8 月の 10 日間, 1967 年 1 月の 2 週間。

e) フォーブス氷河（南極大陸氷床中のひとつの ice stream あるいは outlet glacier) において, 流 速, アブレイション, ストレイングリッド 7 個に よる歪量測定, 氷河図作製, ペトロファプリック スなど。

f) Petrofabric Analysis of Surface Ice near Casey Range；East Antarctica； Jour. Glaciology 投穆 中。

g）航空写真, 地形図はオーストラリア南極探検隊本 部にある。

Antarctic Division, Department of External Affairs, 568 St. Kilda Rd. Melbourne, 3004, Australia

(30) Geophysical Traverse of Ellsworth Highland, Deep Freeze 61

a) C.R. Bentley

b) G.R. Bentley (Univ. of Wisconsin), P. Parks (Univ. of Wisconsin), J.R. Molholm (Ohio State Univ.), 清水 弘 (北・低)

c）西部南極大陸地域（マリーバードランド, エルス ワースハイランド)

d) $1960.11 .14 \sim 1961.2 .11$.

e) 人工地震法 および一般雪氷観测（ピット，コア 一）による, 大陸氷の形状 (表面, 基盤), 眝蔵 量, 年間積雪量等の推定。卓越風の方向, 年平均 気温 $(10 \mathrm{~m}$ 深雪温) 等の調査。

f) Glaciological Studies in West Antarctica, 1960- 